\title{
Investigating Supply Chain Integration Effects on Environmental Performance in the Jordanian Food Industry
}

\author{
Zu'bi M. F. Al-Zu'bi, Ekhleif Tarawneh, Ayman Bahjat Abdallah, Mahmoud A. Fidawi \\ School of Business, The University of Jordan, Amman, Jordan \\ Email: z.alzubi@ju.edu.jo
}

Received 20 April 2015; accepted 29 June 2015; published 2 July 2015

Copyright (C) 2015 by authors and Scientific Research Publishing Inc.

This work is licensed under the Creative Commons Attribution International License (CC BY). http://creativecommons.org/licenses/by/4.0/

cC) (7) Open Access

\begin{abstract}
The purpose of this study was to examine the effects of supply chain integration on environmental performance of food manufacturing companies in Jordan. Data for this study were collected from one hundred and nineteen food companies. To answer the study questions, and to verify its hypotheses, descriptive statistical tools and linear regression tests were used. The study results indicated that supply chain integration positively affected environmental performance. Additionally, the results showed that supply chain integration positively affected environmental control and pollution management.
\end{abstract}

\section{Keywords}

Supply Chain Integration, Environmental Performance, Environmental Control, Pollution Management, Empirical Research

\section{Introduction}

Over the past 15 years, awareness concerning environmental changes was apparently increasing among population and industries. International agencies and national governments have increased their efforts concerning natural resources depletion, ozone depletion, gas emissions and waste reduction. Such efforts entail significant adjustments and changes in production processes and supply chain planning. Therefore, in order to maintain the same level of production, in an environmentally and sustainable way, the traditional way of managing manufacturing operations has to be modified in order to respond to environmental concerns [1].

Supply chain describes the various processes and procedures starting from acquiring the needed raw materials from suppliers and ending with the delivery of finished goods to final consumers. Stock and Boyer [2] defined 
SCM as "The management of a network of relationships within a firm and between interdependent organizations and business units consisting of material suppliers, purchasing, production facilities, logistics, marketing, and related systems that facilitate the forward and reverse flow of materials, services, finances and information from the original producer to final customer with the benefits of adding value, maximizing profitability through efficiencies, and achieving customer satisfaction". Integration was defined as "the quality of the state of collaboration that exists among departments that are required to achieve unity of effort by the demands of the environment" [3]. The definition of supply chain integration is extended in our study to include upstream suppliers and downstream customers. Supply chain integration has been a challenging task for many companies, despite the strong consensus over the strategic importance of its implementation (e.g. [4]-[6]).

While reviewing the supply chain related literature, we found that most of the published research focused on investing the relationship between supply chain integration and operational or business performance (e.g. [7][10]) as well as the linkages between SCI and other operational or business practices (e.g. [11]-[14]). Although sufficient literature existed concerning green supply chain management, a limited number of research papers attempted to discuss the linkages between supply chain integration and environmental performance. Additionally, we failed to find published research concerning this relationship in developing countries. Therefore, this study attempts to address this research gap by investigating the impact of supply chain integration on environmental performance in a developing country, Jordan.

\section{Literature Review}

\subsection{Environmental Situation in Jordan}

Jordan produces significant amount of waste each year. Per capita daily waste in Jordan is around $1 \mathrm{~kg}$, and more than 2 million tons of municipal solid waste is produced per year [15]. Several landfills exist in Jordan. Main ones are Rusaifeh and Al Ghabawi; they receive daily waste of 60 and 3000 tons respectively. Al Ghabawi is a sanitary one where gas produced by waste is used for electrical production. The annual medical and hazardous industrial waste is estimated to be 4000 and 15,000 tons respectively. The recycling rate in Jordan is $5 \%$ of the waste, while in Europe it is around 60\%. Jordan imports $98 \%$ of its energy needs, at a cost of $25 \%$ of its GDP. Zarqa Governorate industrial plants produce $75 \%$ of the total pollution in Jordan [15].

With a 500 million meters deficiency, Jordan is counted the fourth most water poor country. Jordan laws lack waste management texts, but efforts seem underway. For instance, the Gulf of Aqaba Environmental Action Plan (GAEAP) calls to audit of power plant, update plans for oil spills, improve air and marine water quality and manage protected marine areas. The Jordanian wildlife is threatened by industrial pollution. This water shortage led to the damage of Azraq Oasis. The annual estimated water required for Jordan is approximately one billion cubic meters. This number is expected to reach 1.5 billion by year 2020. Cities of Amman, Zarqa, Balqa and Madaba generate $68 \%$ of solid chemical waste. Most of the plants in the central region are located in the country's capital city of Amman and produce chemical products such as detergent and paint. Southern Jordan is home to only eight chemical plants, these produce $31.5 \%$ of the country's chemical waste. The plants based in southern cities such as Karak, Maan, Tafileh, and Aqaba produce mainly paint and fertilizers [15] [16]. Jordan is known for its mineral resources, such as phosphate, potash, uranium, copper, and others. Mining and processing these minerals, is an internationally significant industry in Jordan. Products obtained from the extraction of these minerals are increasingly transformed to chemicals then exported. Possessing these resources can be a basis for downstream cluster of chemical industry [17].

\subsection{Supply Chain Integration}

SCI has been defined as "the degree to which a manufacturer strategically collaborates with its supply chain partners and collaboratively manages intra- and inter-organization processes” [5].

Integration between a buying firm and its suppliers and customers occurs in order to improve operations in the buying firm as well as in the supply network. There is a wide agreement among researchers that internal integration is as important as external integration (e.g. [5] [7] [18] [19]).

One way to view SC integration is based on two perspectives that can be referred to as logistical integration and technological integration [20]. Both perspectives can include suppliers and customers.

Logistical integration has been investigated under different terms such as supply management [21], supplier 
cooperation [7], and supplier involvement [22]. While several factors can be considered in viewing this perspective of integration, including both informational and delivery aspects [23], many researchers has asserted that the idea of information flow between supply chain partners is the main predictor of delivery integration and performance [24]-[26]. Thus, logistical integration is an effective and reliable information exchange mechanism in the supply chain that facilitates delivery activities. Dyer and Nobeoka [27] referred to this type of information as explicit since it involves easily transferable knowledge. Therefore, high logistical integration is characterized by timely and effectively information sharing. Moreover, high logistical integration enhances the flexibility and responsiveness to unexpected situations and facilitates the adaptability of supply chain partners to external requirements and pressures. Information integration is expected to bring different benefits to supply chain partners. Such benefits include, but not limited to, improved communication, commonly used performance measures and improvement goals, ability to adapt changes to product specifications, timely received updates concerning delivery status, improved coordination, supported task completion mechanism, and improved technical infrastructure [7] [19] [28] [29]. Examples of shared information among supply chain partners may include production planning, inventory levels, demand status, lead times, forecasting issues, operating procedures, resources, and logistics [7] [30]-[32].

Technological integration can be defined as an implicit knowledge sharing between two or more partners in the supply chain in strategic aspects [20]. Such aspects may include mass customization [33]-[35] and new product development and design [4] [36]. Information sharing in this type of integration is usually related to specific projects rather than targeting regular operational activities. This shared information facilitates modifications related to process and product aspects as well as to managerial and administrative aspects. As such, technological integration can be regarded as an effective tool to promote innovative activities [37]. Therefore, the degree of such integration depends heavily on the quality and amount of shared information as well as on the degree of involving supply chain partners in process design and new product development activities. Trust and long-term strategic partnership are major prerequisites for such integration [11] [38]. Technological integration offers mutual benefits for supply chain partners. For example, supplier having a sound expertise may assist in process re-design and new product development resulting in increased process effectiveness and shortened new product launch time [39]. On the other hand, the buying firm may assist its suppliers in achieving a high level of quality [22] [34], set up time reduction [40], and in development efforts directed towards strategic manufacturing goals [41] [42]. Process integration is often viewed as a vital aspect of SCI and is expected to contribute to internal operational performance and to external performance to customers and society. It helps in analyzing and developing operational activities among the supply chain partners to meet certain requirements such as customer needs, regulations, and mass customization requirements [11] [41] [43] [44].

\subsection{Environmental Performance}

There is an agreement among researchers that environmental performance lacks a common measure and structure despite the fact that the different measures of environmental performance applied by researchers reflect a common understanding of the concept to mean the environmental effect of a firm [45]. Environmental performance can be viewed as an outcome of Environmental Management System (EMS) [46]. EMS is defined as "part of the overall management system that includes organizational structure, planning activities, responsibilities, practices, procedures, processes and resources for developing, implementing, achieving, reviewing and maintaining the environmental policy" [47]. Sroufe [48] asserted that EMS attempts to enhance compliance and decrease waste. He pointed to compliance as having effective environmental control that allows the firm to comply with legal standards. He further indicated that waste reduction is concerned with pollution prevention starting from the design phase. Whitelaw [49] argued that environmental control includes the identification of all the environmental sides of the firm's activities, prioritizing them using logic, and focusing the efforts to find ways to improve the environmental situation by reducing the environmental effects of significant activities. According to Washington State Department of Ecology [50], pollution prevention was defined as "the use of processes or practices that reduce or eliminate the use of hazardous substances and the generation of pollutants or wastes at the source". They further indicated that successful pollution prevention strategy requires effective environmental control system that includes prevention policy, execution, and measurement and monitoring.

Papadopoulos and Giama [51] indicated that effective environmental performance should include operative measures related to waste and pollution as well as management measures related to control procedures by the 
management. Similarly, Chien and Shih [52] measured environmental performance in terms of management performance concerned with control procedures and operational performance related to pollution and waste disposal.

Based on the above review, we measure environmental performance in terms of the two following dimensions:

Environmental control: Systematic actions undertaken by the firm to promote environmental awareness in order to recognize, control, and reduce acts causing environmental harm so that to ensure environmental compliance to regulations.

Pollution management: Systematic actions undertaken by the firm to reduce and prevent all sources of waste that may potentially generate pollution so that the levels of pollution are minimized.

\subsection{Supply Chain Integration and Environmental Performance}

Dubey et al. [53] using a sample of 174 firms in rubber goods manufacturing companies in India found that supplier integration positively affects environmental performance. Green et al. [54] found that green supply chain practices implemented by manufacturing companies positively affect environmental performance as well as organizational performance. Hsu and Hu [55] investigated the impact of GSCM on environmental performance in Taiwanese electronic manufacturing companies. The results revealed positive relationship between GSCM and environmental performance. Their findings pointed to the crucial role of environmental control procedures such as product testing reports, management commitment, and the existence of environmental database in enhancing environmental performance.

Another study conducted in Taiwan by Chien and Shih [52] found that GSCM practices such as green procurement, environmental management of suppliers, and green manufacturing positively affect environmental performance of electrical and electronic companies. Muma et al. [56] investigated the effect of GSCM on environmental performance in tea processing companies in Kenya. They found that green procurement, green distribution, and green manufacturing were insignificantly related to environmental performance.

\section{Theoretical Framework}

\subsection{Research Framework}

The suggested framework for this study is shown in Figure 1. The framework illustrates the effect of SCI on environmental performance in terms of environmental control and pollution management.

\subsection{Research Hypotheses}

Green and sustainable supply chain management have emerged due to environmental pressures on manufacturing companies to become environmentally friendly. SCI represents the key factor for such survival strategy. Internal environmental operations, green design, and integration with supply chain partners are regarded as main green supply chain practices [57]. Green purchasing has been regarded as a vital enabler to facilitate green production [58]. Govindasamy [59] found that environmental purchasing and sustainable packaging were the main sustainable supply chain management practices to prove their effects on the outcome of sustainable supply chain performance. Although green supply chain has to be initiated internally, it cannot be successfully implemented without integrating key suppliers. Supplier integration assists in protecting resources and controlling negative

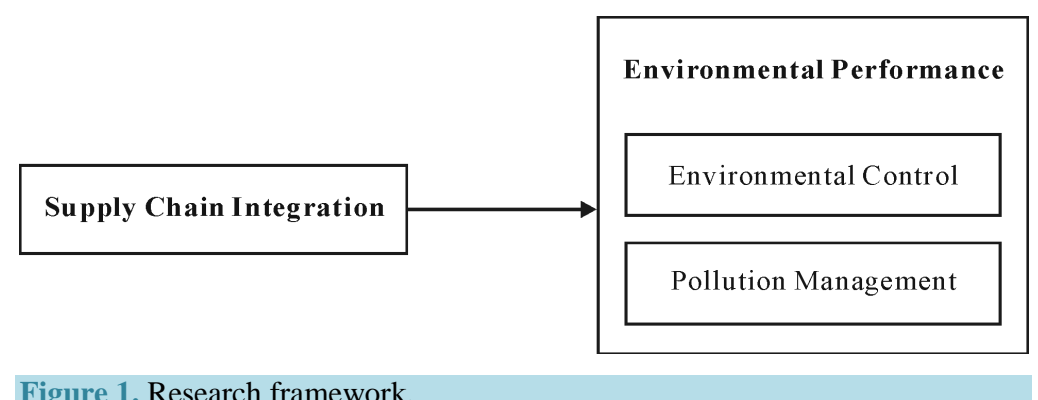

Figure 1. Research framework. 
effects of production operations. The adoption of green or clean technology should be expanded to include suppliers. Such green technology along the supply chain is expected to reduce pollution levels and to encourage the use of pollution control facilities. Hall [60] asserted that supplier integration represents key success factor to achieve environmental change. Such integration will require collaboration in order to assist suppliers in developing environmental capabilities. However, it will require monitoring system in order to inspect suppliers' operational practices and delivered materials [20]. Awareness of environmental issues should be shared with suppliers in order to assure their understanding of environmental regulations and their willingness to comply with green supply chain requirements. Such integration is expected to improve environmental control and facilitate the pollution management resulting in increased environmental performance. Additionally, Internal and crossfunctional integration of information and resources are regarded among main drivers to enhance environmental practices and, thus, environmental performance [48].

Supply chain integration increases company's ability to maximize the usage of green resources while minimizing production waste that leads to pollution [61]. Additionally, green and environmentally-friendly supply chain practices reduce the levels of energy usage, decrease raw materials consumption, reduce inventory levels, shorten production steps, and result in higher accuracy and lower costs [62] [63]. Moreover, supplier integration facilitates the reuse and recycling of raw materials, minimizes the risk of violating regulation with regard to environmental issues, and eliminates the production of hazardous components and waste [52].

H1: Supply chain integration is positively related to the environmental performance.

H1a: Supply chain integration is positively related to the Environmental control.

H1b: Supply chain integration is positively related to the Pollution Management.

\section{Research Method}

\subsection{Sample}

The population of the study represented all food manufacturing companies in Jordan. The survey questionnaire method was used to obtain data for this study. The measurement scales were adopted from previous related studies after conducting a thorough review of the published literature. A total of one hundred and fifty companies were visited personally by the authors in order to improve the representation level. Companies in Jordan usually do not pay attention to survey questionnaires sent by mail or e-mail, therefore we selected the personal visit approach. One manager was selected from each company to fill out the questionnaire. Those managers included operations managers, purchasing managers, supply chain managers, and store managers. Some managers promised to fill out the questionnaires later due to their busy schedules; however, not all of them returned the questionnaires. Other managers declined to participate. Ultimately, one hundred and twenty eight questionnaires were collected. Nine questionnaires were excluded due to different reasons. The number of final usable questionnaires used in the subsequent analysis was one hundred and nineteen representing a response rate of $79.3 \%$. This response rate is regarded high and very satisfactory compared with other studies in Jordan that selected the personal visit approach to companies. For instance, Abdallah [64] and Obeidat et al. [65] received response rates of $59.5 \%$ and $52 \%$ respectively.

\subsection{Instruments}

The question items used in our survey were adapted from some previous studies [5] [7] [24] [45] [52]. Our focus was on ensuring high reliability and validity of our measurement instrument. We used eight question items to measure supply chain integration. Four question items were used to measure environmental control and five question items to measure pollution management. We required respondents to answer the question items using five-point Likert scale where 1 indicated strong disagreement and 5 indicated strong agreement. Next, we used factor analysis with principal component's analysis to evaluate the validity of our constructs. Our criterion was to keep question items that loaded onto one factor with factor loading greater than 0.40 and with eigenvalue for the factor greater than 1 . Two question items did not meet these requirements and were deleted from subsequent analysis. We used Cronbach's $\alpha$-coefficient to assess the reliability of our constructs. All our scales met the recommended standard of $\alpha \geq 0.60$ suggesting that they were internally consistent [66].

Table 1 shows the mean values, standard deviations, and Cronbach's $\alpha$-coefficients for our measurement scales. 


\section{Results}

We started our analysis by testing hypothesis $\mathrm{H} 1$ which indicated that supply chain integration is positively related to environmental performance. Simple regression analysis was used to test the hypothesis. The results of the regression analysis show that supply chain integration, the independent variable, is highly correlated with environmental performance, the dependent variable $(\mathrm{R}=0.726)$ as shown in Table 2 . The table shows that the value of $\mathrm{R}$-square, which is the explained variance, is 0.527 . This means that $52.7 \%$ of the variance (R-square) in the environmental performance has been explained by the supply chain integration. The t-value of 16.576 is significant at $\mathrm{P}<0.01$ level as it is greater than the tabulated value of 1.96. Thus, hypothesis $\mathrm{H} 1$ is accepted.

Next, we tested hypothesis H1a which indicated that supply chain integration is positively related to environmental control. Simple regression analysis was used to test the hypothesis. The results of the regression analysis show that supply chain integration, the independent variable, is highly correlated with environmental control, the dependent variable $(\mathrm{R}=0.646)$ as shown in Table 3 . The table shows that the value of $\mathrm{R}$-square is 0.418 . This means that $41.8 \%$ of the variance in the environmental control has been explained by the supply chain integration. The t-value of 13.309 is significant at $\mathrm{P}<0.01$ indicating that the hypothesis is accepted.

Finally, we tested hypothesis H1b concerning the impact of supply chain integration on pollution management. In a similar manner to previous hypotheses, simple regression analysis was used. The results of the regression analysis show that supply chain integration, the independent variable, is highly correlated with pollution management, the dependent variable $(\mathrm{R}=0.686)$ as shown in Table 4 . The table shows that the value of $\mathrm{R}$-square is

Table 1. Cronbach's $\alpha$-values, means, and standard deviations table type styles.

\begin{tabular}{cccc}
\hline Measurement scale & Cronbach's alpha value & Mean & Standard deviation \\
\hline Supply chain integration & 0.683 & 4.35 & 0.554 \\
Environmental performance & 0.806 & 3.89 & 0.842 \\
Environmental control & 0.745 & 3.70 & 0.961 \\
Pollution management & 0.615 & 4.07 & 0.724
\end{tabular}

Table 2. Regression analysis of environmental performance.

\begin{tabular}{cccccccc}
\hline $\begin{array}{c}\text { Variable } \\
\text { entered }\end{array}$ & $\begin{array}{c}\text { Model } \\
\text { coefficients }\end{array}$ & $\mathrm{R}$ & $\mathrm{R}^{2}$ & Adj. $\mathrm{R}^{2}$ & $\begin{array}{c}\text { Std. error of } \\
\text { the estimate }\end{array}$ & $\mathrm{t}$ & Sig. \\
\hline (Constant) & $-0.406^{*}$ & & & & -1.544 & 0.124 \\
SC integration & $0.726^{* *}$ & 0.726 & 0.527 & 0.525 & 0.52246 & 16.576 & 0.000 \\
\hline
\end{tabular}

*Unstandardized coefficient; ${ }^{* *}$ Standardized coefficient.

Table 3. Regression analysis of environmental control.

\begin{tabular}{cccccccc}
\hline $\begin{array}{c}\text { Variable } \\
\text { entered }\end{array}$ & $\begin{array}{c}\text { Model } \\
\text { coefficients }\end{array}$ & $\mathrm{R}$ & $\mathrm{R}^{2}$ & Adj. $\mathrm{R}^{2}$ & $\begin{array}{c}\text { Std. error of } \\
\text { the estimate }\end{array}$ & $\mathrm{t}$ & Sig. \\
\hline $\begin{array}{c}\text { (Constant) } \\
\text { SC integration }\end{array}$ & $\begin{array}{l}-1.176^{*} \\
0.646^{* *}\end{array}$ & 0.646 & 0.418 & 0.415 & 0.73505 & 13.309 & 0.002 \\
\hline
\end{tabular}

*Unstandardized coefficient; ${ }^{* *}$ Standardized coefficient.

Table 4. Regression analysis of pollution management.

\begin{tabular}{|c|c|c|c|c|c|c|c|}
\hline $\begin{array}{l}\text { Variable } \\
\text { entered }\end{array}$ & $\begin{array}{c}\text { Model } \\
\text { coefficients }\end{array}$ & $\mathrm{R}$ & $\mathrm{R}^{2}$ & Adj. $\mathrm{R}^{2}$ & $\begin{array}{l}\text { Std. error of } \\
\text { the estimate }\end{array}$ & $\mathrm{t}$ & Sig. \\
\hline (Constant) & $0.172^{*}$ & & & & & 0.646 & 0.519 \\
\hline SC integration & $0.686^{* *}$ & 0.686 & 0.470 & 0.468 & 0.52805 & 14.806 & 0.000 \\
\hline
\end{tabular}

"Unstandardized coefficient; ${ }^{* *}$ Standardized coefficient. 
0.470. This means that $47 \%$ of the variance in the pollution management has been explained by the supply chain integration. The t-value of 14.806 is significant at $\mathrm{P}<0.01$ indicating that hypothesis $\mathrm{H} 1 \mathrm{~b}$ is accepted.

\section{Discussion and Conclusion}

This study attempted to investigate the effect of supply chain integration on environmental performance in food companies in Jordan. While previous research indicated a positive and significant influence of GSCM on environmental performance in developed countries, lack of studies in developing countries was evident in the published literature. Our results are consistent with the results of other studies conducted in the developed countries (e.g. [67]-[69]). The results imply that awareness concerning environmental issues is taking place in developing countries. As environmental pressures on manufacturing companies increase, the challenge will be to select suppliers who are devoted and keen to improve their environmental performance and adapt their operations to green requirements. Such suppliers should bear in mind that environmentally-friendly manufacturing and supply chain integration should not imply that quality and cost can be sacrificed [70]. Food companies willing to achieve high environmental performance have to assist their suppliers in improving their environmental performance. Such capable and aware suppliers can potentially be integrated into design projects to develop green products [71].

Our findings were inconsistent with the findings of Muma et al. [56] who found insignificant impact of GSCM on environmental performance in Kenya. Such inconsistency could be attributed to the lack of environmental control in Kenyan companies as opposite to Jordanian food companies. Environmental control allows companies to enhance environmental performance and set control systems and procedures that assign environmental-related responsibilities to different departments and managers. Prior training to managers and workers is required in order to establish an effective accountability policy [72].

The results also indicate that pollution management has been significantly explained by the supply chain integration. A major problem in Jordan is that the recycling rate is $5 \%$ of the waste compared with a rate of $60 \%$ in Europe [15]. While related governmental agencies face real challenges to increase this low rate, SC integration represents an essential approach for food companies to reduce their waste and overall pollution. SC integration promotes environmental practices such as solid return policy, usage of less hazardous materials in the products, and improvements of the usage of recycled materials. The involvement and education of employee and supply chain partners stimulate the overall environmental management system and contribute to higher levels of environmental performance.

The limitation of our study is that only food companies are included in our sample. Generally, the environmental situation and awareness in these companies are regarded favorable compared with other manufacturing sectors. Future studies are needed with a sample representing different manufacturing sectors so that to improve the generalizability of the results. Another limitation is that contextual factors such as company size, age, and type are not considered in our study. Such factors may influence the proposed relationship; therefore further similar studies with contextual factors are needed. Additional limitation exists in this study concerning the validity of the findings. Data were collected from single respondent in each food company. Although this method of data collection is widely used in empirical studies, multiple respondents each of whom addresses her particular field of expertise are expected to enhance the validity of the results.

\section{References}

[1] Vachon, S. and Klassen, R.D. (2008) Environmental Management and Manufacturing Performance: The Role of Collaboration in the Supply Chain. International Journal of Production Economics, 111, 299-315. http://dx.doi.org/10.1016/j.ijpe.2006.11.030

[2] Stock, J. and Boyer, S. (2009) Developing a Consensus Definition of Supply Chain Management: A Qualitative Study. International Journal of Physical Distribution \& Logistics Management, 39, 690-711. http://dx.doi.org/10.1108/09600030910996323

[3] Lee, H. and Whang, S. (2001) E-Business and Supply Chain Integration, Stanford University. Global Supply Chain Management Forum SGSCMF-W220, November 2001, 17-26.

[4] Al-Abdallah, G.M., Abdallah, A.B. and Bany Hamdan, K. (2014) The Impact of Supplier Relationship Management on Competitive Performance of Manufacturing Firms. International Journal of Business and Management, 9, $192-202$. http://dx.doi.org/10.5539/ijbm.v9n2p192

[5] Flynn, B.B., Huo, B. and Zhao, X. (2010) The Impact of Supply Chain Integration on Performance: A Contingency and 
Configuration Approach. Journal of Operations Management, 28, 58-71. http://dx.doi.org/10.1016/j.jom.2009.06.001

[6] Tsinopoulos, C. and Al-Zu'bi, Z.M.F. (2014) Lead Users, Suppliers, and Experts: The Exploration and Exploitation Trade-Off in Product Development. International Journal of Technology Marketing, 9, 6-20. http://dx.doi.org/10.1504/IJTMKT.2014.058080

[7] Abdallah, A.B., Obeidat, B.Y. and Aqqad, N.O. (2014) The Impact of Supply Chain Management Practices on Supply Chain Performance in Jordan: The Moderating Effect of Competitive Intensity. International Business Research, 7, 1327. http://dx.doi.org/10.5539/ibr.v7n3p13

[8] Al-Ettayyem, R. and Al-Zu’bi, Z.M.F. (2015) Investigating the Effect of Total Quality Management Practices on Organizational Performance in the Jordanian Banking Sector. International Business Research, 8, 1-12. http://dx.doi.org/10.5539/ibr.v8n3p79

[9] Lee, C.W., Kwon, I.G. and Severance, D. (2007) Relationship between Supply Chain Performance and Degree of Linkage among Supplier, Internal Integration, and Customer. Supply Chain Management: An International Journal, 12, 444-452. http://dx.doi.org/10.1108/13598540710826371

[10] Sezen, B. (2008) Relative Effects of Design, Integration and Information Sharing on Supply Chain Performance. Supply Chain Management: An International Journal, 13, 233-240. http://dx.doi.org/10.1108/13598540810871271

[11] Abdallah, A. and Matsui, Y. (2009) The Impact of Lean Practices on Mass Customization and Competitive Performance of Mass-Customizing Plants. Proceedings of the 20th Annual Production and Operations Management Society (POMS) Conference, Orlando, 1-4 May 2009.

[12] Abdallah, A. and Phan, C.A. (2007) The Relationship between Just-in-Time Production and Human Resource Management, and Their Impact on Competitive Performance. Yokohama Business Review, 28, 27-57.

[13] Al-Zu’bi, Z.M.F. and Tsinopoulos, C. (2012) Suppliers versus Lead Users: Examining Their Relative Impact on Product Variety. Journal of Product Innovation Management, 29, 667-680. http://dx.doi.org/10.1111/j.1540-5885.2012.00932.x

[14] Vanichchinchai, A. and Igel, B. (2009) Total Quality Management and Supply Chain Management: Similarities and Differences. The TQM Journal, 21, 249-260. http://dx.doi.org/10.1108/17542730910953022

[15] Zafar, S. (2014) Biomass Energy, Middle East, Renewable Energy. http://www.ecomena.org/tag/bioenergy/

[16] Hadadin, N. and Tarawneh, Z. (2007) Environmental Issues in Jordan, Solutions and Recommendations. American Journal of Environmental Sciences 3, 30-36. http://dx.doi.org/10.3844/ajessp.2007.30.36

[17] Ramadna, A. (2012) Mining Sector in Jordan: Current Solution and Investment Opportunities. Ministry of Industry and Trade Jordan.

http://ec.europa.eu/enterprise/policies/raw-materials/files/docs/euromed_presentations/ramadna_mining_sector_jourda n_en.pdf

[18] Al-Zu'bi, Z.M.F., Heizer, J. and Render, B. (2013) Operations Management. 1st Arab World Edition, Pearson, London.

[19] Li, S., Ragu-Nathan, B., Ragu-Nathan, T.S. and Subba Rao, S. (2004) The Impact of Supply Chain Management Practices on Competitive Advantage and Organizational Performance. Omega, 34, 107-124. http://dx.doi.org/10.1016/j.omega.2004.08.002

[20] Vachon, S. and Klassen, R.D. (2006) Extending Green Practices across the Supply Chain. International Journal of Operations \& Production Management, 26, 795-821. http://dx.doi.org/10.1108/01443570610672248

[21] Shin, H., Collier, D.A. and Wilson, D.D. (2000) Supply Management Orientation and Supplier/Buyer Performance. Journal of Operations Management, 18, 317-333. http://dx.doi.org/10.1016/S0272-6963(99)00031-5

[22] Phan, A.C., Abdallah, A.B. and Matsui, Y. (2011) Quality Management Practices and Competitive Performance: Empirical Evidence from Japanese Manufacturing Companies. International Journal of Production Economics, 133, 518529. http://dx.doi.org/10.1016/j.ijpe.2011.01.024

[23] Frohlich, M.T. and Westbrook, R. (2001) Arcs of Integration: An International Study of Supply Chain Strategies. Journal of Operations Management, 19, 185-200. http://dx.doi.org/10.1016/S0272-6963(00)00055-3

[24] Chen, I.J. and Paulraj, A. (2004) Towards a Theory of Supply Chain Management: The Constructs and Measurements. Journal of Operations Management, 22, 119-150. http://dx.doi.org/10.1016/j.jom.2003.12.007

[25] Stock, G.N., Greis, N.P. and Kasarda, J.D. (2000) Enterprise Logistics and Supply Chain Structure: The Role of Fit. Journal of Operations Management, 18, 531-547. http://dx.doi.org/10.1016/S0272-6963(00)00035-8

[26] Tsinopoulos, C. and Al-Zu’bi, Z.M.F. (2012) Clockspeed Effectiveness of Lead Users and Product Experts. International Journal of Operations \& Production Management, 32, 1097-1118. http://dx.doi.org/10.1108/01443571211265710

[27] Dyer, J. and Nobeoka, K. (2000) Creating and Managing a High-Performance Knowledge-Sharing Network: The 
Toyota Case. Strategic Management Journal, 21, 345-367.

http://dx.doi.org/10.1002/(SICI)1097-0266(200003)21:3<345::AID-SMJ96>3.0.CO;2-N

[28] Al-Zu’bi, Z.M.F., Alshurideh, M., Abuhamed, A. and Ghannajeh, A.M. (2015) A Qualitative Analysis of Product Innovation in Jordan's Pharmaceutical Sector. European Science Journal, 11, 474-503.

[29] Gimenez, C. and Sierra, V. (2013) Sustainable Supply Chains: Governance Mechanisms to Greening Suppliers. Journal of Business Ethics, 116, 189-203. http://dx.doi.org/10.1007/s10551-012-1458-4

[30] Al-Zu’bi, Z.M.F. and Tsinopoulos, C. (2012) An Outsourcing Model for Lead Users: An Empirical Investigation. Production Planning and Control, 24, 1-10.

[31] Sakka, O. and Botta-Genoulaz, V. (2009) A Model of Factors Influencing the Supply Chain Performance. Proceedings of CIE, Troyes, 6-9 July 2009, 913-918. http://dx.doi.org/10.1109/iccie.2009.5223796

[32] Singh, R. K. (2013) Prioritizing the Factors for Coordinated Supply Chain Using Analytic Hierarchy Process (AHP). Measuring Business Excellence, 17, 80-98. http://dx.doi.org/10.1108/13683041311311383

[33] Abdallah, A. and Matsui, Y. (2008) Customer Involvement, Modularization of Products, and Mass Customization: Their Relationship and Impact on Value to Customer and Competitiveness. Proceedings of the 3rd World Conference on Production and Operations Management, Tokyo, 5-8 August 2008.

[34] Al-Zu’bi, Z.M.F., Al-Lozi, M., Dahiyat, S., Alshurideh, M. and Al Majali, A. (2012) Examining the Effect of Quality Management Practices on Product Variety. European Journal of Economics, Finance and Administrative Sciences, 1, $1-19$.

[35] Al-Zu’bi, Z.M.F., Dahiyat, S.E., Warrad, T., Shannak, R.O. and Masa’deh, R.M. (2012) Investigating the Effect of Foreign Direct Investment Technology Transfer on Mass Customization Capability in Jordan’s Manufacturing Sector. International Research Journal of Finance and Economics, 94, 79-90.

[36] Al-Zu’bi, Z.M.F. and Khamees, B.A. (2014) Activity-Based Costing vs. Theory of Constraints: An Empirical Study into Their Effect on the Cost Performances of NPD Initiatives. International Journal of Economics and Finance, 6, 157-165. http://dx.doi.org/10.5539/ijef.v6n12p157

[37] Abdallah, A.B., Phan, C.A. and Matsui, Y. (2015) Investigating the Effects of Managerial and Technological Innovations on Operational performance and Customer Satisfaction of Manufacturing Companies. International Journal of Business Innovation and Research, in Press. http://www.inderscience.com/info/ingeneral/forthcoming.php?jcode=ijbir

[38] Alkalha, Z., Al-Zu’bi, Z.M.F., Al-Dmour, H., Alshurideh, M. and Masa'deh, R. (2012) Investigating the Effect of Human Resource Policies on Organizational Performance: An Empirical Study on Commercial Banks Operating in Jordan. European Journal of Economics, Finance and Administrative Sciences, 1, 94-102.

[39] Kaufman, A., Wood, C. and Theyel, G. (2000) Collaboration and Technology Linkages: A Strategic Supplier Typology. Strategic Management Journal, 21, 649-663. http://dx.doi.org/10.1002/(SICI)1097-0266(200006)21:6<649::AID-SMJ108>3.0.CO;2-U

[40] Abdallah, A. and Matsui, Y. (2007) Just in Time Production and Total Productive Maintenance: Their Relationship and Impact on JIT and Competitive Performances. Proceedings of the 9th International Decision Sciences Institute Conference, Bangkok, 11-15 July 2007.

[41] Abdallah, A.B., Phan, A.C. and Matsui, Y. (2009) Investigating the Relationship between Strategic Manufacturing Goals and Mass Customization. Proceedings of the 16th International Annual European Operations Management Association (EurOMA), Goteborg, 14-17 June 2009.

[42] Al Hasan, R. and Al-Zu'bi, Z.M.F. (2014) Evaluating the Relationships between Lean Manufacturing Dimensions and Radical Product Innovation in the Jordanian Pharmaceutical Sector. European Scientific Journal, 10, 230-258.

[43] Al-Zu’bi, Z.M.F. (2010) Collaboration in Mass Customisation: Exploring the Impacts of Suppliers and Lead Users. 1st Edition, VDM Verlag, Saarbrücken.

[44] Zairi, M. (1997) Business Process Management: A Boundary Less Approach to Modern Competitiveness. Business Process Re-Engineering \& Management Journal, 3, 64-80. http://dx.doi.org/10.1108/14637159710161585

[45] Afagachie, C. (2013) The Relationship between Corporate Environmental Performance and Corporate Financial Performance-Using the Framework of Corporate Environmental Policy Implementation. Unpublished Dissertation, University of Bristol, Bristol.

[46] Halkos, G. and Sepetis, A. (2007) Can Capital Markets Respond to Environmental Policy of Firms? Evidence from Greece. Ecological Economics, 63, 578-587. http://dx.doi.org/10.1016/j.ecolecon.2006.12.015

[47] Gelber, M. (2004) BS 8555 Case Study. BEST Conference, Brussels, 10 February 2004.

[48] Sroufe, R. (2003) Effects of Environmental Management Systems on Environmental Management Practices and Operations. Production and Operations Management, 12, 416-431. http://dx.doi.org/10.1111/j.1937-5956.2003.tb00212.x 
[49] Whitelaw, K. (2004) ISO 14001 Environmental Systems Handbook. 2nd Edition, Elsevier Butterworth-Heinemann, Oxford.

[50] Washington State Department of Ecology (1997) Hazardous Waste and Toxics Reduction Program. Publication \#97-401. https://fortress.wa.gov/ecy/publications/publications/97401.pdf

[51] Papadopoulos, A.M. and Giama, E. (2007) Environmental Performance Evaluation of Thermal Insulation Materials and Its Impact on the Building. Building and Environment, 42, 2178-2187.

http://dx.doi.org/10.1016/j.buildenv.2006.04.012

[52] Chien, M.K. and Shih, L.H. (2007) An Empirical Study of the Implementation of Green Supply Chain Management Practices in the Electrical and Electronic Industry and Their Relation to Organizational Performances. International Journal of Environmental Science and Technology, 4, 383-394.

[53] Dubey, R., Gunasekaran, A. and Ali, S. (2015) Exploring the Relationship between Leadership, Operational Practices, Institutional Pressures and Environmental Performance: A Framework for Green Supply Chain. International Journal of Production Economics, 160, 120-132. http://dx.doi.org/10.1016/j.ijpe.2014.10.001

[54] Green, K.W., Pamela, Z., Meacham J. and Bhadauria, S.V. (2012) Green Supply Chain Management Practices: Impact on Performance. Supply Chain Management: An International Journal, 17, 290-305. http://dx.doi.org/10.1108/13598541211227126

[55] Hsu, C.W. and Hu, A.H. (2008) Green Supply Chain Management in the Electronic Industry. International Journal of Environmental Science and Technology, 5, 205-216. http://dx.doi.org/10.1007/BF03326014

[56] Muma, B., Nyaoga, R., Matwere, R. and Nyambega, E. (2014) Green Supply Chain Management and Environmental Performance Among Tea Processing Firms in Kericho County-Kenya. International Journal of Economics, Finance and Management Sciences, 2, 270-276. http://dx.doi.org/10.11648/j.ijefm.20140205.11

[57] Zhu, Q. and Sarkis, J. (2006) An Inter-Sectoral Comparison of Green Supply Chain Management in China: Drivers and Practices. Journal of Cleaner Production, 14, 472-486. http://dx.doi.org/10.1016/j.jclepro.2005.01.003

[58] Min, H. and Galle, W.P. (2001) Green Purchasing Practices of U.S. Firms. International Journal of Operations \& Production Management, 21, 1222-1238. http://dx.doi.org/10.1108/EUM0000000005923

[59] Govindasamy, V. (2010) Sustainable Supply Chain Management (SSCM) Practices: Antecedents and Outcomes on Sustainable Supply Chain Performance. Unpublished Master’s Thesis, Universiti Sains Malaysia, Penang.

[60] Hall, J. (2000) Environmental Supply Chain Dynamics. Journal of Cleaner Production, 8, 455-471. http://dx.doi.org/10.1016/S0959-6526(00)00013-5

[61] Gopalakrishnan, K., Yusuf, Y.Y., Musa, A., Abubakar, T. and Ambursa, H.M. (2012) Sustainable Supply Chain Management: A Case Study of British Aerospace (BAe) Systems. International Journal of Production Economics, 140, 193-203. http://dx.doi.org/10.1016/j.ijpe.2012.01.003

[62] Luthra, S., Kumar, V., Kumar, S. and Haleem, A. (2010) Green Supply Chain Management Issues: A Literature Review Approach. Journal of Information, Knowledge and Research in Mechanical Engineering, 1, 12-20.

[63] Porter, M.E. and Van der Linde, C. (1995) Green and Competitive: Ending the Stalemate. Harvard Business Review, 73, $120-134$

[64] Abdallah, A.B. (2013) The Influence of "Soft” and "Hard” Total Quality Management (TQM) Practices on Total Productive Maintenance (TPM) in Jordanian Manufacturing Companies. International Journal of Business and Management, 8, 1-13. http://dx.doi.org/10.5539/ijbm.v8n21p1

[65] Obeidat, B.Y., Masa'deh, R.M. and Abdallah, A.B. (2014) The Relationships among Human Resource Management Practices, Organizational Commitment, and Knowledge Management Processes: A Structural Equation Modeling Approach. International Journal of Business and Management, 9, 9-26. http://dx.doi.org/10.5539/ijbm.v9n3p9

[66] Nunnally, J. (1978). Psychometric Theory. 2nd Edition, McGraw-Hill, New York.

[67] Hsu, C.W. and Hu, A.H. (2009) Applying Hazardous Substance Management to Supplier Selection Using Analytic Network Process. Journal of Cleaner Production, 17, 255-264. http://dx.doi.org/10.1016/j.jclepro.2008.05.004

[68] Ku, C.Y., Chang, C.T. and Ho, H.P. (2010) Global Supplier Selection Using Fuzzy Analytic Hierarchy Process and Fuzzy Goal Programming. Quality \& Quantity, 44, 623-640. http://dx.doi.org/10.1007/s11135-009-9223-1

[69] Van Hoof, B. and Lyon, T.P. (2013) Cleaner Production in Small Firms Taking Part in Mexico’s Sustainable Supplier Program. Journal of Cleaner Production, 41, 270-282. http://dx.doi.org/10.1016/j.jclepro.2012.09.023

[70] Luthra, S., Garg, D. and Haleem, A. (2013) Identifying and Ranking of Strategies to Implement Green Supply Chain Management in Indian Manufacturing Industry Using Analytical Hierarchy Process. Journal of Industrial Engineering and Management, 6, 930-962. http://dx.doi.org/10.3926/jiem.693

[71] Rao, P. (2002) Greening the Supply Chain: A New Initiative in South East Asia. International Journal of Operations 
and Production Management, 22, 632-655. http://dx.doi.org/10.1108/01443570210427668

[72] Dasgupta, S., Hettige, H. and Wheeler, D. (1998) What Improves Environmental Performance? Evidence from Mexican Industry. Development Research Group, World Bank.

http://web.worldbank.org/archive/website01004/WEB/IMAGES/106506-3.PDF 